\title{
Utilisation of Maize Bran as a Wheat Bran Substitute on Quail (Coturnix sp.) Production Performances in the Sudano-Guinean Zone of Cameroon
}

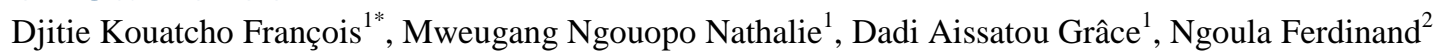

${ }^{1}$ Laboratory of Applied Zoology, Department of Biological Sciences, Faculty of Sciences, University of Ngaoundéré, Cameroon

${ }^{2}$ Laboratory of Animal Productions, Department of Animal Sciences, Faculty of Agronomy and Agricultural Sciences, University of Dschang, Cameroon

DOI: $10.36347 /$ sjavs.2020.v07i06.002

| Received: 07.05.2020 | Accepted: 14.05.2020 | Published: 19.06.2020

*Corresponding author: Djitie Kouatcho François

Abstract

Original Research Article

The present study was conducted in order to evaluate the effect of the substitution of wheat bran by maize bran on quail production performances. For this purpose, 240 day-old unsexed quails of similar body weight $(6.86 \pm 0.68 \mathrm{~g})$ were divided into 15 batches of 16 birds. 5 experimental diets (T0, T1, T2, T3 and T4) were formulated on the basis of the level $(0,25,50,75$ and $100 \%$ respectively) of substitution of wheat bran by maize bran and each was randomly distributed to 3 batches in a completely randomized design with 5 treatments repeated 3 times each. At 7 weeks of age, 3 males and 3 females per batch were sacrificed for carcass analysis, data were collected on growth performances, carcass characteristics, and some reproductive characteristics. The main results showed that regardless of sex, the feed intake of the control treatment T0 $(845.72 \pm 18.18 \mathrm{~g})$, was significantly higher than the values of treatments T2 $(731.16 \pm 4.93 \mathrm{~g})$ and $\mathrm{T} 4(801.83 \pm 11.34 \mathrm{~g})$ but was similar to T1 $(826.72 \pm 38.60 \mathrm{~g})$ and $\mathrm{T} 3(814.16 \pm 19.81 \mathrm{~g})$. In males, body weight ranged from $201.6 \pm 9.49 \mathrm{~g}$ (T2) to $214.87 \pm 3.56 \mathrm{~g}$ (T4) but did not differ significantly between treatments. In females, the body weight of the control batch $(225.32 \pm 4.07 \mathrm{~g})$ was similar to the other treatments. Only the neck, gizzard, abdominal fat proportion relative to body weight were significantly affected by the substitution levels. The characteristics of testes and eggs remained broadly comparable. It was concluded that maize bran can be used up to $50 \%$ as a substitute for wheat bran in the diet of quails in the growing and early laying phases.

Keywords: Substitution, wheat bran, maize bran, growth, reproduction, quail.

Copyright @ 2020: This is an open-access article distributed under the terms of the Creative Commons Attribution license which permits unrestricted use, distribution, and reproduction in any medium for non-commercial use (NonCommercial, or CC-BY-NC) provided the original author and source are credited.

\section{INTRODUCTION}

The quail is a source of great interest in Cameroon because of its many assets, including its resistance to disease, the low production cost associated with its small size ( 80 to $300 \mathrm{~g}$ ), its rapid growth and relatively short life cycle that can reach 3 to 4 generations per year [1], its high egg production of 250 to 350 eggs per female per year [2,3] as well as the potential therapeutic virtues of these eggs [4]. As for any other species, feed occupies the highest cost position in breeding and can contribute nearly $70 \%$ of the production cost [5]. As a result, the low incomes of households make it difficult for them to purchase it on a regular basis [6], hence the need to seek other ways of reducing it. Given this shortage, it is necessary to find alternatives to lower the cost of production, the use of unconventional feed ingredients in animals is one of the possibilities. In the northern part of Cameroon in general, and in the Adamawa region particularly, feeding habits lead the local population to process maize before its consumption. As a result, maize bran is obtained in quantities that are thrown away or used in an anarchic way as animal feed. Well-treated and wellpackaged maize bran could be formally incorporated into animal feed and would also contribute to the valorisation of local by-products. The present work aims to evaluate in quails, the effect of the substitution of wheat bran by maize bran on: growth performance, carcass characteristics, and some reproductive characteristics.

\section{MATERIALS AND METHODS \\ Presentation of the study area}

The present study was carried out in Ngaoundéré, capital of the Adamawa region located between the 6th and 8th degrees North latitude and between the 11th and 15th degrees East longitude. It covers about $62,000 \mathrm{~km}^{2}$ and belongs to the agroecological zone known as the High Guinean Savannah. 
Climate is Sudano-Guinean, mild and cool, characterized by two seasons: a rainy season (April to October) and a dry season (November to March). The average annual temperature varies from 23 to $25^{\circ} \mathrm{C}$ and annual rainfall between 900 and $1500 \mathrm{~mm}$ with an average annual humidity of $70 \%$ [7].

\section{Animal material, experimental design and test execution}

A total of 240 day-old, unsexed quail with an average body weight of $6.86 \pm 0.68 \mathrm{~g}$ were divided into 15 batches of 16 birds in order to form comparable batches on a weight basis. At 3 weeks of age, sex was determined and 12 birds, (6 males and 6 females) were selected per batch for the finishing phase. They were housed at a density of 28 subjects $/ \mathrm{m} 2$ in cages made of wooden plank and wire mesh with a small mesh size to accommodate the small size of the birds. Based on the formula of a growth feed, five experimental diets (T0, $\mathrm{T} 1, \mathrm{~T} 2, \mathrm{~T} 3$, and T4) of different levels of substitution $(0,25,50,75$, and $100 \%)$ of wheat bran by maize bran were formulated. The percent composition and calculated chemical characteristics of the experimental diets are noted in the table below:

Table-1: Percent composition of experimental diets

\begin{tabular}{|l|l|l|l|l|l|}
\hline \multirow{2}{*}{ Ingrédients (Kg) } & \multicolumn{5}{|c|}{ Experimental diets } \\
\cline { 2 - 6 } & $\mathbf{T 0}(\mathbf{0 \%})$ & $\mathbf{T 1}(\mathbf{2 5 \% )}$ & $\mathbf{T 2} \mathbf{( 5 0 \% )}$ & $\mathbf{T 3}(\mathbf{7 5 \%})$ & $\mathbf{T 4}(\mathbf{1 0 0} \%)$ \\
\hline Maize & 60 & 60 & 60 & 60 & 60 \\
\hline Soybean meal & 16 & 16 & 16 & 16 & 16 \\
\hline Wheat bran & 5 & 3.75 & 2.5 & 1.25 & 0 \\
\hline Corn bran & 0 & 1.25 & 2.5 & 3.75 & 5 \\
\hline Fishmeal & 7 & 7 & 7 & 7 & 7 \\
\hline Bone meal & 0.5 & 0.5 & 0.5 & 0.5 & 0.5 \\
\hline Shellfish meal & 0.5 & 0.5 & 0.5 & 0.5 & 0.5 \\
\hline CMVA 5\% Flesh & 5 & 5 & 5 & 5 & 5 \\
\hline Peanut cake & 5 & 5 & 5 & 5 & 5 \\
\hline Palm oil & 1 & 1 & 1 & 1 & 1 \\
\hline Total & 100 & 100 & 100 & 100 & 100 \\
\hline $\begin{array}{l}\text { Calculated chemical characteristics (\%MS) of the basic diet (T0): Crude Protein content } \\
\text { 22\%, Metabolisable Energy 3000Kcal, fat 4.47\%, calcium 1.23\%, Phosphorus 0.64\%, Lysine } \\
\text { 1.32\%, Methionine 1.48\%. CMVA: Concentrated Nitrogenous Minerals and Vitamins }\end{array}$ \\
\hline
\end{tabular}

Each of the 5 experimental diets was randomly assigned to 3 batches in a completely randomized design with 5 treatments repeated 3 times each. Water and feed were distributed ad libitum throughout the trial, birds from all batches benefited from similar husbandry conditions.

\section{Data Collection}

\section{Growth Parameters}

Feed consumption: feed was weighed at the beginning and distributed on a daily basis. The remains of each experimental unit were also weighed every 7 days, using a $1 \mathrm{~g}$ precision electronic scale, and subtracted from the amount of feed distributed to obtain the feed intake.

Body weights: at the beginning of the trial and every 7 days thereafter, all animals were weighed on an empty stomach in the morning between 8 and 10 a.m., using an electronic scale with a 500g capacity and $0.01 \mathrm{~g}$ accuracy. Weekly weight gain was obtained by calculating the difference between two consecutive body weights.

Feed intake and body weight gain data were used to calculate the feed conversion ratio by dividing the feed intake by the weight gain for the same period.

\section{Carcass Characteristics}

At 07 weeks of age, 03 males and 03 females per batch (09 males and 09 females per treatment) were slaughtered for carcass evaluation by the Genchev and Mihaylova [8] method. Data were collected on carcass, liver, heart, gizzard, thigh, chest and wing weights.

Based on the collected data, the following parameters were calculated:

Carcass weight $=$ Body weight $-($ head + legs + blood + feathers + viscera) weight

$$
\text { Carcass yield }(\%)=\frac{\text { Carcass weight }(\mathrm{g})}{\text { Body weight }(\mathrm{g})} \times 100
$$

Relative weight of parts or organs $(\%)=\frac{\text { Weight of parts or organs }(\mathrm{g})}{\text { Body weight }(\mathrm{g})} \times 100$ 


\section{Testis and Egg Characteristics}

After quails had been slaughtered, testes were collected and weighed together and separately using an electronic balance with a capacity of $500 \mathrm{~g}$ and $0.01 \mathrm{~g}$ accuracy. Subsequently, diameter and height were measured using a digital caliper with a range of $150 \mathrm{~mm}$ and accuracy of $0.01 \mathrm{~mm}$. From the data collected, the following calculations were made:

Shape index $=$ Diameter $/$ Height

Weight ratio $=\frac{\text { Left testis weight }(\mathrm{g})}{\text { Right testis weight }(\mathrm{g})} \times 100$

$$
\text { Gonado-Somatic Index }(\%)=\frac{\text { Testes weight }(\mathrm{g})}{\text { Body weight }(\mathrm{g})} \times 100
$$

At 7 and 8 weeks of age, eggs were collected and counted. Using the preceding instruments, the weight, diameter and height of the eggs were taken and allowed us to calculate the shape index and the laying rate according to the following formula:

$$
\text { Weekly laying rate }(\%)=\frac{\text { Number of eggs laid }}{\text { Number of females placed in reproduction } \times 7} \times 100
$$

\section{STATISTICAL ANALYSIS}

Data were subjected to a one-factor analysis of variance (ANOVA). When differences between treatments were found, means were separated using Duncan's test at the 5\% significance level. IBM SPSS Statistics 25.0 software was used for the various analyses.

\section{RESULTS}

\section{Effect of substituting wheat bran with maize bran on growth parameters}

Table-2 shows the effect of substituting wheat bran by corn bran on the average quail production performances at 7 weeks. It shows that the substitution of wheat bran by corn bran reduced feed intake and the significantly lower value was noted at $50 \%$ substitution compared to the other substitution levels which were comparable between $\mathrm{T} 0, \mathrm{~T} 1$ and $\mathrm{T} 3$ on the one hand and between $\mathrm{T} 1$ and $\mathrm{T} 4$ on the other hand.

Body weight and weight gain were also comparable in males and regardless of sex, although overall in the last case, there was a slight increase in the values of these two parameters in treatments with maize bran. In females, it was noted that corn bran substitution resulted in no significant variation in body weight and weight gain between the control and other groups, although there was a slight increase at the 25 and $50 \%$ substitution levels. Overall, the significantly lower feed conversion ratio was found with the $50 \%$ substitution treatment compared to other treatments that exhibited comparable values.

\begin{tabular}{|c|c|c|c|c|c|}
\hline \multirow[t]{2}{*}{ Characteristics } & \multirow{2}{*}{$\begin{array}{l}\text { Experimental } \\
\text { diets }\end{array}$} & \multicolumn{4}{|c|}{$\begin{aligned} \text { Production performances } \\
\end{aligned}$} \\
\hline & & $\begin{array}{l}\text { Feed intake } \\
(\mathrm{g})\end{array}$ & $\begin{array}{l}\text { Body weight } \\
\text { (g) }\end{array}$ & $\begin{array}{l}\text { Weekly weight } \\
\text { gain (g) }\end{array}$ & $\begin{array}{l}\text { Feed Conversion } \\
\text { Ratio (g) }\end{array}$ \\
\hline \multirow[t]{5}{*}{ Females } & T0 & & $225.32 \pm 4.07^{\mathrm{abc}}$ & $31.20 \pm 0.65^{\mathrm{ab}}$ & $3.90 \pm 0.12^{b}$ \\
\hline & T1 & & $230.02 \pm 3.95^{\mathrm{bc}}$ & $31.88 \pm 0.56^{\mathrm{b}}$ & $3.80 \pm 0.22^{b}$ \\
\hline & $\mathbf{T 2}$ & & $232.35 \pm 2.88^{\mathrm{c}}$ & $32.19 \pm 0.43^{b}$ & $3.24 \pm 0.05^{\mathrm{a}}$ \\
\hline & T3 & & $222.27 \pm 10.4^{\mathrm{ab}}$ & $30.81 \pm 1.45^{\mathrm{ab}}$ & $3.77 \pm 0.22^{b}$ \\
\hline & T4 & & $219.45 \pm 4.93^{\mathrm{a}}$ & $30.36 \pm 0.76^{\mathrm{a}}$ & $3.77 \pm 0.13^{b}$ \\
\hline \multirow[t]{5}{*}{ Males } & T0 & & $206.35 \pm 12.77^{\mathrm{a}}$ & $28.49 \pm 1.78^{\mathrm{a}}$ & $4.24 \pm 0.23^{\mathrm{b}}$ \\
\hline & T1 & & $208.50 \pm 11.39^{\mathrm{a}}$ & $28.84 \pm 1.64^{\mathrm{a}}$ & $4.06 \pm 0.36^{\mathrm{ab}}$ \\
\hline & $\mathbf{T 2}$ & & $201.6 \pm 9.49^{\mathrm{a}}$ & $27.71 \pm 1.45^{\mathrm{a}}$ & $3.77 \pm 0.21^{\mathrm{a}}$ \\
\hline & T3 & & $202.27 \pm 2.45^{\mathrm{a}}$ & $27.93 \pm 0.38^{\mathrm{a}}$ & $3.77 \pm 0.11^{b}$ \\
\hline & T4 & & $214.87 \pm 3.56^{\mathrm{a}}$ & $29.74 \pm 0.48^{\mathrm{a}}$ & $3.88 \pm 0.10^{\mathrm{ab}}$ \\
\hline \multirow[t]{5}{*}{ Mixed } & T0 & $845.72 \pm 18.18^{c}$ & $215.83 \pm 13.41^{\mathrm{a}}$ & $28.83 \pm 1.79^{\mathrm{a}}$ & $4.07 \pm 0.25^{\mathrm{b}}$ \\
\hline & T1 & $826.72 \pm 38.60^{b c}$ & $219.26 \pm 13.95^{\mathrm{a}}$ & $31.54 \pm 3.15^{\mathrm{a}}$ & $3.93 \pm 0.31^{b}$ \\
\hline & $\mathbf{T 2}$ & $731.16 \pm 4.93^{\mathrm{a}}$ & $217.00 \pm 17.64^{\mathrm{a}}$ & $29.87 \pm 5.15^{\mathrm{a}}$ & $3.50 \pm 0.31^{\mathrm{a}}$ \\
\hline & T3 & $814.16 \pm 19.81^{b c}$ & $212.27 \pm 12.79^{\mathrm{a}}$ & $29.57 \pm 2.26^{\mathrm{a}}$ & $3.98 \pm 0.28^{b}$ \\
\hline & T4 & $801.83 \pm 11.34^{b}$ & $217.16 \pm 4.67^{\mathrm{a}}$ & $27.94 \pm 5.39^{\mathrm{a}}$ & $3.82 \pm 0.12^{b}$ \\
\hline
\end{tabular}

Table-2: Average production performances at 7 weeks as a function of the experimental diets

$a, b, c:$ on the same column and for the same sex, the values assigned with the same letter are not significantly different $(P>0.05)$.

\section{Feed Intake}

Figure-1 shows the evolution of feed intake as a function of the experimental diets, and it appears that in the starter phase, T2, T3 and T4 treatments were similar and significantly lower than the other treatments. In the finishing phase (4 to 7 weeks), feed intake of the T2 batch was significantly lower than that of other batches. The same was observed over the entire rearing period, where the control treatment also presented the significantly highest feed intake. 


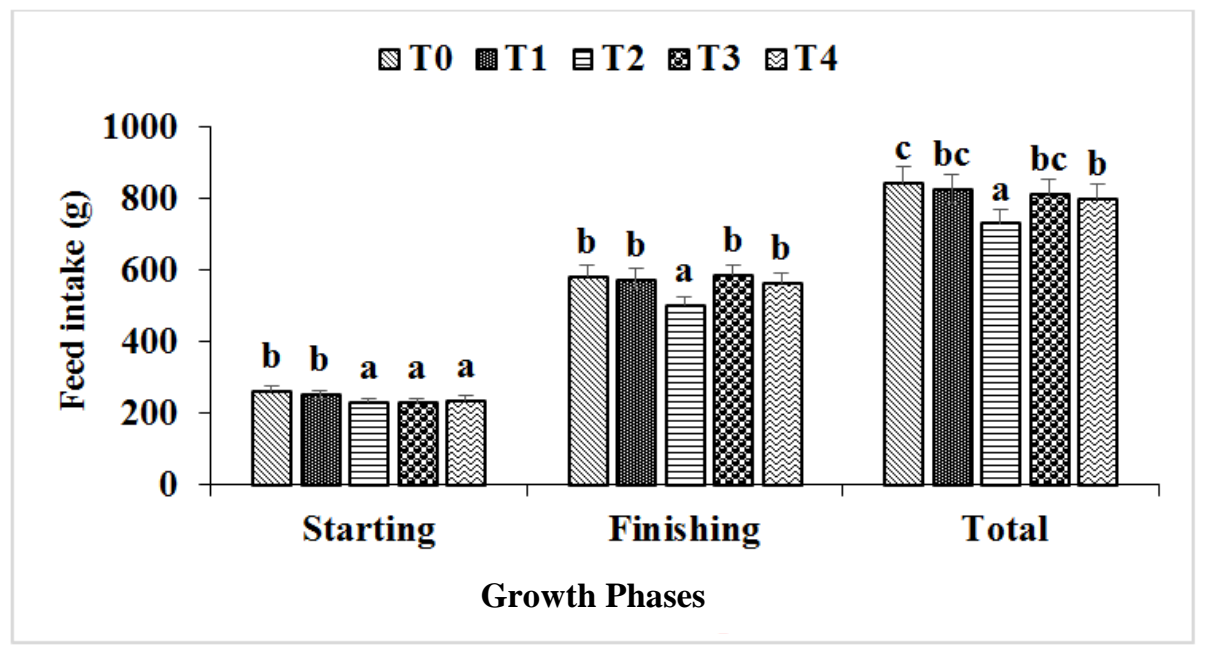

Fig-1: Weekly change in feed intake according to the experimental diets and growth phases.

\section{Body weight and average weight gain}

The weekly evolution of quail body weight showed the same pattern regardless of the experimental diet and sex (Figure-2). In males, there were no significant differences in body weight regardless of treatment. On the other hand, in females, with the exception of week 7 where all values were comparable regardless of the experimental diets, T2 treatment generally induced significantly $(\mathrm{P}<0.05)$ higher body weight than $\mathrm{T} 4$ treatment although it was comparable to the other treatments.
Weight gain decreased significantly throughout the study. In males, with the exception of week 6 where T2 treatment induced significantly $(\mathrm{P}<$ $0.05)$ greater weight gain, weight gain values were always similar $(\mathrm{P}>0.05)$. In females, weight gain remained comparable between the control and other treatments, although a slight increase was noted with the 25 and $50 \%$ substitutions of wheat bran by maize bran.
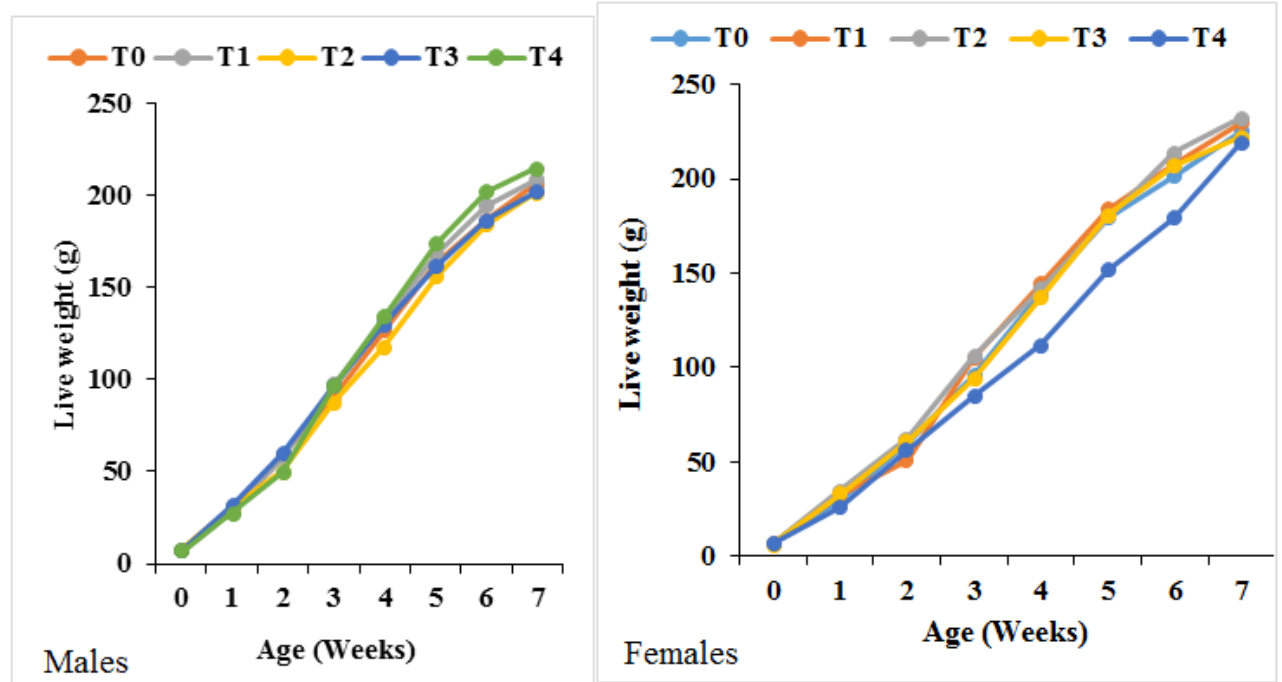

Fig-2: Body weight evolution of quails as a function of the experimental diets and age

\section{Feed Conversion Ratio}

Feed conversion ratio (FCR) increased significantly in all treatments with age (Figure 3 ). At the end of the starting phase, the significantly $(\mathrm{P}<0.05)$ highest FCR $(3.12 \pm 0.21 \mathrm{~g})$ was recorded with the control group compared to treatment $\mathrm{T} 3(2.55 \pm 0.19 \mathrm{~g})$ which was the lowest, but similar to the values of the treatments substituted at 25,50 and $100 \%$ of wheat bran by maize bran. At the end of the finishing phase, T3 treatment induced the significantly $(\mathrm{P}<0.05)$ highest FCR value $(5.60 \pm 0.22 \mathrm{~g})$ compared to T2 $(4.41 \pm 0.24 \mathrm{~g})$, which was also similar to the values of the control and $100 \%$ corn bran-substituted treatments. For the entire growing period, the 50\% substitution treatment induced the significantly lower FCR compared to the other treatments which also presented similar values for this parameter. 


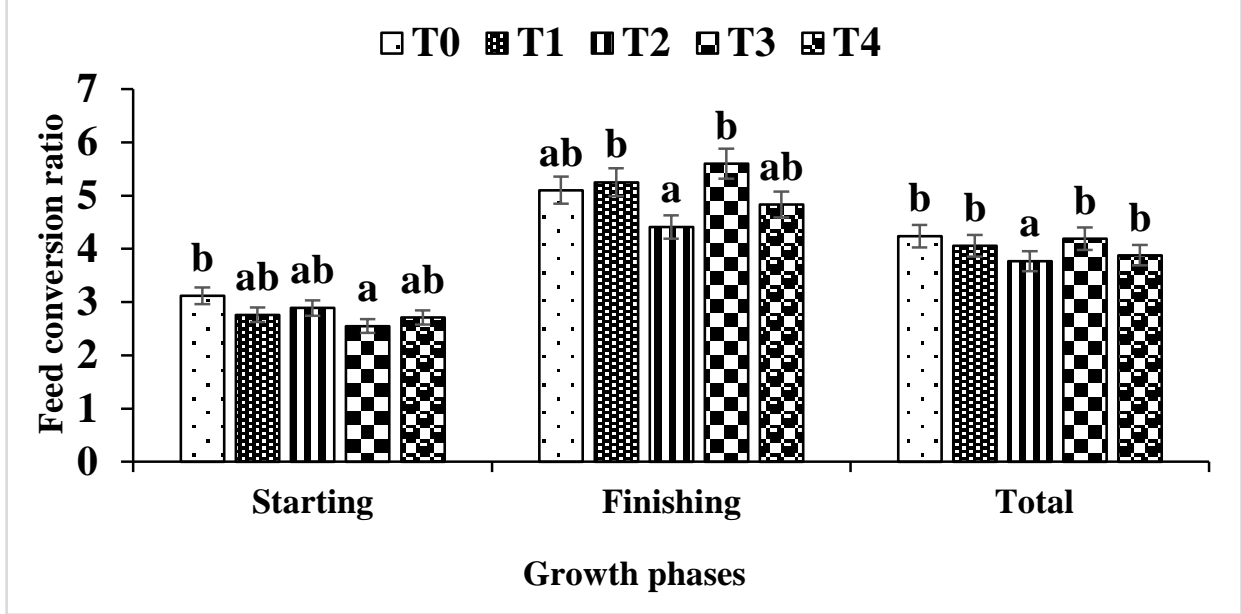

Fig-3: Evolution of feed conversion ratio as function of the experimental diets and growth phases

Carcass characteristics and relative weight of parts and organs to body weight of quails at 7 weeks of age

Carcass characteristics and relative weight of parts to body weight are summarized in Table-3. Carcass yield was similar $(\mathrm{P}>0.05)$ in males at all substitution levels. In females and regardless of sex, the significantly lowest $(\mathrm{P}<0.05)$ yields were overall recorded with the control group (T0) compared to other treatments which were otherwise comparable $(\mathrm{P}>$ $0.05)$.

Table-3: Carcass characteristics at 7 weeks of age as function of the experimental diets

\begin{tabular}{|c|c|c|c|c|c|c|}
\hline Characteristics & Sex & \multicolumn{5}{|c|}{ Experimental diets } \\
\hline & & $\mathrm{T0}(\mathrm{n}=18)$ & $\mathrm{T} 1(\mathrm{n}=18)$ & $\mathrm{T} 2(\mathrm{n}=18)$ & $\mathrm{T} 3(\mathrm{n}=18)$ & $\mathrm{T} 4(\mathrm{n}=18)$ \\
\hline \multirow[t]{3}{*}{ Carcass yield } & Male & $69.76 \pm 1.62^{\mathrm{a}}$ & $69.40 \pm 1.16^{\mathrm{a}}$ & $72.50 \pm 2.52^{\mathrm{a}}$ & $74.31 \pm 2.47^{\mathrm{a}}$ & $72.37 \pm 4.47^{\mathrm{a}}$ \\
\hline & Female & $62.65 \pm 7.90^{\mathrm{a}}$ & $74.56 \pm 5.41^{\mathrm{b}}$ & $72.28 \pm 5.71^{\mathrm{ab}}$ & $72.09 \pm 6.36^{\mathrm{ab}}$ & $72.36 \pm 2.55^{\mathrm{ab}}$ \\
\hline & Mixed & $66.20 \pm 6.42^{\mathrm{a}}$ & $71.98 \pm 4.49^{\mathrm{ab}}$ & $72.39 \pm 3.95^{\mathrm{b}}$ & $73.20 \pm 4.48^{\mathrm{b}}$ & $71.46 \pm 3.76^{\mathrm{ab}}$ \\
\hline \multirow[t]{3}{*}{ Chest } & Male & $28.47 \pm 2.45^{\mathrm{a}}$ & $27.27 \pm 0.42^{\mathrm{a}}$ & $28.16 \pm 2.68^{\mathrm{a}}$ & $27.79 \pm 0.36^{\mathrm{a}}$ & $28.79 \pm 2.32^{\mathrm{a}}$ \\
\hline & Female & $25.81 \pm 0.58^{\mathrm{a}}$ & $27.67 \pm 1.93^{\mathrm{a}}$ & $27.99 \pm 2.42^{\mathrm{a}}$ & $26.52 \pm 1.99^{\mathrm{a}}$ & $25.11 \pm 0.29^{\mathrm{a}}$ \\
\hline & Mixed & $27.14 \pm 2.15^{\mathrm{a}}$ & $27.47 \pm 1.27^{\mathrm{a}}$ & $28.08 \pm 2.29^{\mathrm{a}}$ & $27.16 \pm 1.45^{\mathrm{a}}$ & $26.84 \pm 2.59^{\mathrm{a}}$ \\
\hline \multirow[t]{3}{*}{ Thigh } & Male & $16.66 \pm 2.33^{\mathrm{a}}$ & $15.91 \pm 0.79^{\mathrm{a}}$ & $16.00 \pm 1.16^{\mathrm{a}}$ & $15.17 \pm 1.25^{\mathrm{a}}$ & $15.47 \pm 1.68^{\mathrm{a}}$ \\
\hline & Female & $14.31 \pm 0.58^{\mathrm{a}}$ & $15.25 \pm 0.37^{\mathrm{a}}$ & $14.63 \pm 0.96^{\mathrm{a}}$ & $14.38 \pm 1.10^{\mathrm{a}}$ & $14.95 \pm 0.52^{\mathrm{a}}$ \\
\hline & Mixed & $15.48 \pm 1.99^{\mathrm{a}}$ & $15.58 \pm 0.66^{\mathrm{a}}$ & $15.31 \pm 1.21^{\mathrm{a}}$ & $14.78 \pm 1.14^{\mathrm{a}}$ & $15.02 \pm 1.26^{\mathrm{a}}$ \\
\hline \multirow[t]{3}{*}{ Wing } & Male & $6.46 \pm 0.46^{\mathrm{b}}$ & $5.57 \pm 0.14^{\mathrm{a}}$ & $5.60 \pm 0.23^{\mathrm{a}}$ & $5.49 \pm 0.51^{\mathrm{a}}$ & $5.82 \pm 0.41^{\mathrm{b}}$ \\
\hline & Female & $5.28 \pm 0.79^{\mathrm{a}}$ & $5.32 \pm 0.49^{\mathrm{a}}$ & $5.13 \pm 0.62^{\mathrm{a}}$ & $6.02 \pm 0.77^{\mathrm{a}}$ & $4.79 \pm 0.52^{\mathrm{a}}$ \\
\hline & Mixed & $5.87 \pm 0.86^{\mathrm{a}}$ & $5.45 \pm 0.35^{\mathrm{a}}$ & $5.37 \pm 0.49^{\mathrm{a}}$ & $5.75 \pm 0.65^{\mathrm{a}}$ & $5.36 \pm 0.62^{\mathrm{a}}$ \\
\hline \multirow[t]{3}{*}{ Neck } & Male & $7.03 \pm 0.82^{b}$ & $4.37 \pm 0.36^{\mathrm{a}}$ & $5.35 \pm 0.67^{\mathrm{a}}$ & $5.15 \pm 0.38^{\mathrm{a}}$ & $4.94 \pm 0.47^{\mathrm{a}}$ \\
\hline & Female & $5.95 \pm 0.30^{b}$ & $4.71 \pm 0.39^{\mathrm{a}}$ & $4.90 \pm 0.23^{\mathrm{a}}$ & $5.06 \pm 0.75^{\mathrm{a}}$ & $4.64 \pm 0.64^{\mathrm{a}}$ \\
\hline & Mixed & $6.49 \pm 0.81^{b}$ & $4.54 \pm 0.39^{\mathrm{a}}$ & $5.12 \pm 0.51^{\mathrm{a}}$ & $5.11 \pm 0.53^{\mathrm{a}}$ & $4.76 \pm 0.46^{\mathrm{a}}$ \\
\hline \multirow[t]{3}{*}{ Back } & Male & $14.61 \pm 1.32^{\mathrm{a}}$ & $13.52 \pm 1.15^{\mathrm{a}}$ & $13.54 \pm 0.86^{\mathrm{a}}$ & $14.37 \pm 1.66^{\mathrm{a}}$ & $13.96 \pm 2.22^{\mathrm{a}}$ \\
\hline & Female & $14.96 \pm 0.44^{\mathrm{a}}$ & $14.37 \pm 1.38^{\mathrm{a}}$ & $14.45 \pm 0.17^{\mathrm{a}}$ & $14.35 \pm 1.72^{\mathrm{a}}$ & $13.70 \pm 0.45^{\mathrm{a}}$ \\
\hline & Mixed & $14.78 \pm 0.90^{\mathrm{a}}$ & $13.94 \pm 1.22^{\mathrm{a}}$ & $14.00 \pm 0.75^{\mathrm{a}}$ & $14.36 \pm 1.51^{\mathrm{a}}$ & $13.66 \pm 1.49^{\mathrm{a}}$ \\
\hline
\end{tabular}

$a, b, c:$ on the same line, values assigned with the same letter are not significantly different $(P>0.05)$.

\section{Organ Proportions}

Relative weights of some organs as a function of the experimental diets at 7 weeks of age (table 4) shows that all experimental diets induced no significant effect $(\mathrm{P}<0.05)$ on the relative weights of the heart and liver regardless of sex. This is also true for the relative weight of gizzard in females and regardless of sex. In
The different substitution levels had no significant effect on the proportions of chest, thigh and back. Male wing proportions in T0 and T4 were comparable $(\mathrm{P}>0.05)$ and significantly $(\mathrm{P}<0.05)$ higher compared to $\mathrm{T} 1, \mathrm{~T} 2$ and $\mathrm{T} 3$ treatments. The proportions of the neck of the control group were significantly higher than those of the other batches, which were otherwise comparable. males however, the relative gizzard weights of the $100 \%$ corn bran substitute treatment were significantly lower than those of the other treatments, which were otherwise similar. The proportions of abdominal fat in the males of the control group were significantly $(\mathrm{P}<$ $0.05)$ greater than that of the group fed a diet containing $100 \%$ corn bran, comparable to the other treatments 
Table-4: Relative weights of some organs as a function of the experimental diets at 7 weeks of age

\begin{tabular}{|l|l|l|l|l|l|l|}
\hline Characteristics (\%BW) & Sex & \multicolumn{5}{|c|}{ Experimental diets } \\
\hline \multirow{4}{*}{ Liver } & & $\mathrm{T} 0(\mathrm{n}=18)$ & $\mathrm{T} 1(\mathrm{n}=18)$ & $\mathrm{T} 2(\mathrm{n}=18)$ & $\mathrm{T} 3(\mathrm{n}=18)$ & $\mathrm{T} 4(\mathrm{n}=18)$ \\
\hline \multirow{5}{*}{ Heart } & Male & $1.23 \pm 0.24^{\mathrm{a}}$ & $1.43 \pm 0.15^{\mathrm{a}}$ & $1.26 \pm 0.22^{\mathrm{a}}$ & $1.15 \pm 0.15^{\mathrm{a}}$ & $1.55 \pm 0.34^{\mathrm{a}}$ \\
\cline { 2 - 7 } & Female & $1.58 \pm 0.30^{\mathrm{a}}$ & $1.41 \pm 0.27^{\mathrm{a}}$ & $1.27 \pm 0.04^{\mathrm{a}}$ & $1.53 \pm 0.41^{\mathrm{a}}$ & $1.14 \pm 0.07^{\mathrm{a}}$ \\
\cline { 2 - 7 } & Mixed & $1.41 \pm 0.31^{\mathrm{a}}$ & $1.42 \pm 0.20^{\mathrm{a}}$ & $1.27 \pm 0.14^{\mathrm{a}}$ & $1.34 \pm 0.34^{\mathrm{a}}$ & $1.35 \pm 0.30^{\mathrm{a}}$ \\
\hline \multirow{5}{*}{ Gizzard } & Male & $0.87 \pm 0.11^{\mathrm{a}}$ & $0.91 \pm 0.09^{\mathrm{a}}$ & $0.81 \pm 0.03^{\mathrm{a}}$ & $0.80 \pm 0.11^{\mathrm{a}}$ & $0.88 \pm 0.12^{\mathrm{a}}$ \\
\cline { 2 - 7 } & Female & $0.84 \pm 0.18^{\mathrm{a}}$ & $0.79 \pm 0.15^{\mathrm{a}}$ & $0.79 \pm 0.07^{\mathrm{a}}$ & $0.88 \pm 0.05^{\mathrm{a}}$ & $0.71 \pm 0.12^{\mathrm{a}}$ \\
\cline { 2 - 7 } & Mixed & $0.85 \pm 0.13^{\mathrm{a}}$ & $0.85 \pm 0.13^{\mathrm{a}}$ & $0.80 \pm 0.05^{\mathrm{a}}$ & $0.84 \pm 0.09^{\mathrm{a}}$ & $0.80 \pm 0.12^{\mathrm{a}}$ \\
\hline Abdominal fat & Male & $2.04 \pm 0.62^{\mathrm{b}}$ & $2.23 \pm 0.17^{\mathrm{b}}$ & $2.33 \pm 0.36^{\mathrm{b}}$ & $2.17 \pm 0.17^{\mathrm{b}}$ & $1.65 \pm 0.46^{\mathrm{a}}$ \\
\cline { 2 - 7 } & Female & $2.35 \pm 0.10^{\mathrm{a}}$ & $2.28 \pm 0.30^{\mathrm{a}}$ & $2.43 \pm 0.22^{\mathrm{a}}$ & $2.45 \pm 0.08^{\mathrm{a}}$ & $2.35 \pm 0.23^{\mathrm{a}}$ \\
\cline { 2 - 7 } & Mixed & $2.20 \pm 0.18^{\mathrm{a}}$ & $2.25 \pm 0.22^{\mathrm{a}}$ & $2.38 \pm 0.27^{\mathrm{a}}$ & $2.31 \pm 0.19^{\mathrm{a}}$ & $2.00 \pm 0.50^{\mathrm{a}}$ \\
\hline & Male & $1.69 \pm 0.15^{\mathrm{b}}$ & $1.07 \pm 0.31^{\mathrm{ab}}$ & $1.49 \pm 0.60^{\mathrm{ab}}$ & $0.98 \pm 0.39^{\mathrm{ab}}$ & $0.84 \pm 0.45^{\mathrm{a}}$ \\
\cline { 2 - 7 } & Female & $0.72 \pm 0.18^{\mathrm{a}}$ & $1.21 \pm 0.38^{\mathrm{a}}$ & $0.97 \pm 0.41^{\mathrm{a}}$ & $1.11 \pm 0.13^{\mathrm{a}}$ & $0.76 \pm 0.18^{\mathrm{a}}$ \\
\cline { 2 - 7 } & Mixed & $1.21 \pm 0.55^{\mathrm{a}}$ & $1.14 \pm 0.32^{\mathrm{a}}$ & $1.23 \pm 0.54^{\mathrm{a}}$ & $1.05 \pm 0.27^{\mathrm{a}}$ & $0.80 \pm 0.30^{\mathrm{a}}$ \\
\hline
\end{tabular}

$a$, $b$ : on the same line, values assigned with the same letter are not significantly different $(P<0.05)$.

Testicular characteristics as a function of the level of substitution of wheat bran by corn bran

Testicular weights, left to right testicular weight ratio, and testicular diameter relative to experimental diets (Table-5) were not significantly $(\mathrm{P}>0.05)$ affected. Although comparable, there was a decrease in the gonado-somatic index (GSI) in treatments T1, T3 and T4 compared to the control. There was no significant difference $(\mathrm{P}>0.05)$ in left testicular height and mean testicular height with any of the treatments. Treatment $\mathrm{T} 2$ induced significantly $(\mathrm{P}>$ $0.05)$ higher right testicular height values compared to T3 comparable to the other treatments that were otherwise comparable to each other. Treatments T1, T2 and T4 induced comparable shape index values for the left testicle but significantly higher than the control treatment. The control group induced significantly $(\mathrm{P}<$ 0.05) higher shape index values for the right testes compared to $\mathrm{T} 2$ but similar to other treatments that were otherwise comparable to $\mathrm{T} 2$.

Table-5: Gonad characteristics as a function of the experimental diets

\begin{tabular}{|c|c|c|c|c|c|c|}
\hline \multirow{2}{*}{\multicolumn{2}{|c|}{ Characteristics }} & \multicolumn{4}{|c|}{ Experimental diets } & \multirow[b]{2}{*}{ T4 $(n=9)$} \\
\hline & & T0 $(n=9)$ & T1 $(\mathrm{n}=9)$ & T2 $(\mathrm{n}=9)$ & T3 $(n=9)$ & \\
\hline \multirow[t]{3}{*}{ Testicular weith } & Left & $2.39 \pm 0.05^{\mathrm{a}}$ & $2.27 \pm 0.57^{\mathrm{a}}$ & $2.67 \pm 0.17^{\mathrm{a}}$ & $1.55 \pm 0.62^{\mathrm{a}}$ & $1.85 \pm 1.08^{\mathrm{a}}$ \\
\hline & Right & $2.39 \pm 0.51^{\mathrm{a}}$ & $2.20 \pm 0.48^{\mathrm{a}}$ & $2.54 \pm 0.14^{\mathrm{a}}$ & $1.50 \pm 0.70^{\mathrm{a}}$ & $2.05 \pm 1.19^{\mathrm{a}}$ \\
\hline & Total & $4.79 \pm 0.57^{\mathrm{a}}$ & $4.47 \pm 1.05^{\mathrm{a}}$ & $5.21 \pm 0.31^{\mathrm{a}}$ & $3.05 \pm 1.32^{\mathrm{a}}$ & $3.90 \pm 2.27^{\mathrm{a}}$ \\
\hline \multicolumn{2}{|c|}{ Left/Right Testis weight } & $1,02 \pm($ & $1.02 \pm 0.03^{\mathrm{a}}$ & $1.05 \pm 0.01^{\mathrm{a}}$ & $1.05 \pm 0.09^{\mathrm{a}}$ & $0.90 \pm 0.00^{\mathrm{a}}$ \\
\hline \multicolumn{2}{|c|}{ GSI } & $2,55 \pm 0,26^{\mathrm{a}}$ & $2.05 \pm 0.46^{\mathrm{a}}$ & $2.55 \pm 0.37^{\mathrm{a}}$ & $1.47 \pm 0.69^{\mathrm{a}}$ & $1.89 \pm 1.07^{\mathrm{a}}$ \\
\hline \multirow[t]{3}{*}{ Height } & Left & $12.75 \pm 4.14^{\mathrm{a}}$ & $21.32 \pm 1.01^{\mathrm{a}}$ & $22.52 \pm 0.18^{\mathrm{a}}$ & $19.72 \pm 3.34^{\mathrm{a}}$ & $19.42 \pm 5.27^{\mathrm{a}}$ \\
\hline & Right & $19.37 \pm 0.81^{\mathrm{ab}}$ & $21.59 \pm 2.71^{\mathrm{ab}}$ & $23.50 \pm 0.80^{b}$ & $17.92 \pm 3.32^{\mathrm{a}}$ & $19.20 \pm 2.64^{\mathrm{ab}}$ \\
\hline & Mean & $20.81 \pm 0.46^{\mathrm{a}}$ & $21.46 \pm 1.86^{\mathrm{a}}$ & $23.01 \pm 0.31^{\mathrm{a}}$ & $18.82 \pm 3.33^{\mathrm{a}}$ & $19.31 \pm 3.96^{\mathrm{a}}$ \\
\hline \multirow[t]{3}{*}{ Diameter } & Left & $10.71 \pm 0$. & $12.91 \pm 1.09^{\mathrm{a}}$ & $13.36 \pm 0.65^{\mathrm{a}}$ & $10.03 \pm 1.53^{\mathrm{a}}$ & $12.35 \pm 3.83^{\mathrm{a}}$ \\
\hline & Right & 13.63 & $12.48 \pm$ & $11.87 \pm$ & $10.74 \pm 0.37^{\mathrm{a}}$ & 12.7 \\
\hline & Mean & 12.17 & $12.70 \pm 0$ & $12.62 \pm 0$ & $10.38 \pm 0.95^{\mathrm{a}}$ & $12.55 \pm 3.99^{\mathrm{a}}$ \\
\hline \multirow[t]{2}{*}{ Shape index } & Left & $0.48 \pm 0.00^{\mathrm{a}}$ & $0.60 \pm 0.02^{\mathrm{b}}$ & $0.59 \pm 0.03^{b}$ & $0.50 \pm 0.00^{\mathrm{a}}$ & $0.63 \pm 0.02^{\mathrm{b}}$ \\
\hline & Right & $0.70 \pm 0.00^{b}$ & $0.58 \pm 0.08^{\mathrm{ab}}$ & $0.50 \pm 0.00^{\mathrm{a}}$ & $0.61 \pm 0.09^{\mathrm{ab}}$ & $0.65 \pm 0.12^{\mathrm{ab}}$ \\
\hline
\end{tabular}

$a, b:$ on the same line, values assigned with the same letter are not significantly different $(P>0.05)$.

\section{External characteristics of eggs as a function of experimental diets}

The effect of replacing wheat bran by maize bran on external egg characteristics is shown in Table6. It appears that control treatment induced the lowest egg-laying rate compared to other treatments and the treatment that induced the highest egg-laying rate was recorded with treatment $\mathrm{T} 1(30.5 \%)$. It was also found that the egg weight of the treatment substituted at $50 \%$ by corn bran induced egg weight similar to that of the control group and T3 but significantly $(\mathrm{P}<0.05)$ lower than those of treatments $\mathrm{T} 1$ and $\mathrm{T} 4$. The same treatment induced the lowest significantly $(\mathrm{P}<0.05)$ large egg diameter value compared to treatment $\mathrm{T} 4$ but was similar to treatments. Egg height in all substitution levels was comparable to the control treatment, however, the T2 treatment induced significantly lower values than the T1, T3 and T4 treatments. Egg shape index remained comparable $(\mathrm{P}>0.05)$ between treatments, although a slight decrease was observed from the control batch compared to the other treatments. 
Table-6: External quail eggs characteristics as a function of the experimental diets

\begin{tabular}{|l|l|l|l|l|l|}
\hline \multirow{2}{*}{ Characteristics } & \multicolumn{5}{|c|}{ Experimental diets } \\
\cline { 2 - 6 } & T0 & T1 & T2 & T3 & T4 \\
\hline Laying rate & 22 & 30.5 & 24.5 & 30 & 26.5 \\
\hline Weight & $11.17 \pm 0.72^{\mathrm{ab}}$ & $11.90 \pm 0.82^{\mathrm{b}}$ & $10.39 \pm 0.95^{\mathrm{a}}$ & $11.30 \pm 1.51^{\mathrm{ab}}$ & $11.91 \pm 1.12^{\mathrm{b}}$ \\
\hline Diameter & $25.44 \pm 1.33^{\mathrm{ab}}$ & $25.41 \pm 0.45^{\mathrm{ab}}$ & $24.36 \pm 0.55^{\mathrm{a}}$ & $25.24 \pm 1.93^{\mathrm{ab}}$ & $25.68 \pm 1.61^{\mathrm{b}}$ \\
\hline Height & $30.91 \pm 1.31^{\mathrm{ab}}$ & $31.75 \pm 0.71^{\mathrm{b}}$ & $31.89 \pm 1.38^{\mathrm{a}}$ & $31.78 \pm 1.87^{\mathrm{b}}$ & $31.89 \pm 0.88^{\mathrm{b}}$ \\
\hline Shape index & $0.82 \pm 0.05^{\mathrm{a}}$ & $0.80 \pm 0.02^{\mathrm{a}}$ & $0.80 \pm 0.02^{\mathrm{a}}$ & $0.79 \pm 0.05^{\mathrm{a}}$ & $0.80 \pm 0.05^{\mathrm{a}}$ \\
\hline
\end{tabular}

$a$, $b$ : on the same line, values assigned with the same letter are not significantly different $(P>0.05)$.

\section{DISCUSSION}

Our study results showed that, with the exception of treatment $\mathrm{T} 2$, which recorded the lowest feed intake (FI), compared to the control batch, there was a reduction in FI with the level of substitution of wheat bran by corn bran. This could be explained by an increasing unappetizability with the level of substitution of wheat bran by corn bran. This eventual nonappetibility could be justified by processing and storage conditions that are not always optimal. Indeed, according to Kiendrébéogo [9], unavailability, inaccessibility and poor storage conditions of these byproducts are major constraints to their use in animal feed. FI values obtained in the context of our study are close to those obtained by Bobga [10] who noted an increase in FI by substituting fish meal by cricket meal in quail feed at $0,15,30$ and $45 \%$ of but opposite to those of Djitie et al., [11] who supplemented quail feed with Moringa oleifera leaf powder (0, 1, 2 and 3\%) did not observe any significant difference, which could be explained by the fact that Moringa leaf powder would be palatable to these birds due to its high vitamin and nutrient content [12].

The diets substituted with corn bran were all comparable to the control treatment. Although there was a slight increase in body weight with the level of substitution in males, there was an increase in PV between the control treatment and $50 \%$ substitution. The high values of body weight recorded at T2 and T1 reflect optimal feed composition in females and males respectively. In males, body weight increases with the level of substitution of wheat bran by maize bran, which is consistent with studies conducted by Djitie et al., [13] and Bensalah [14]. As with body weight, average weight gain increased with the level of maize bran in groups $\mathrm{T} 1$ and $\mathrm{T} 4$. This increase was significant in females. The lowest values were once again recorded with T4 treatment, several studies following the same logic have shown that the more the protein level in the diet is increased beyond a certain point, in animals in the growth phase, this would most often have undesirable effects on animal weight, both on protein synthesis [15] and on hormonal balance [16], due to the presence of high proportions of fiber [17].

In males and regardless of sex, the substitution of wheat bran by corn bran induced a significant reduction in the feed conversion ratio (FCR) compared to the control. In females, it was also found that the use of corn bran resulted in better food assimilation, which was not the case in males. Overall, feed conversion ratio values were higher in the control treatment and regardless of sex, which could indicate poor feed utilization (Djitie et al., 2015). Higher FCR recorded for the control batches for the entire period, from 3.7 to 10.2 were noted in the work of Odunsi et al., [18] and Attia et al. [19] as it was also noted in the work of Odunsi et al., [18] and Attia et al., [19]. Lower FCR between 2.72 and 3.32 were reported by Ghally and Abd El-Latif [20]. According to Kanyinji and Moonga [21], the increase in the FCR may be the consequence of waste and its reduction may be related to an increased fiber content. Indeed, the high FCR values obtained during the last weeks of quail growth are justified with the low weight gains and an increase in FI noted for the same period thus reveal the decrease in the bird's ability to convert feed at the end of growth [2, 22].

Chest, thigh and back proportions were not significantly $(\mathrm{P}>0.05)$ affected by the different levels of substitution of wheat bran by corn bran. These results are in contrast to the observations of Corrêa et al., [23] who reported that the proportion of wishbone increased significantly with the protein level of the diet in female quails. The low proportions of female versus male wishbones in the present study are similar to that of Bonos et al., [24] where the male's carcass yield at 42 days was reported to be higher $(78.03 \%)$ than the female's (72), 66\%) and those of Alkan et al., [25] who showed that at 42 days, carcass yield of Japanese quail weighing 256 and $139 \mathrm{~g}$ respectively were 67.8 and $67.6 \%$, but higher than those of Vali [26] who obtained at 50 days a carcass yield of $61.81 \%$. These variations suggest that quail carcass yield would depend mainly on the sex and age of the animals at slaughter.

Proportions of heart and liver to body weight were similar between treatments, although there were slight increases with the substitution rate. Similar trends have been obtained by other authors [24, 27]; although lower proportions (1.66 to $1.99 \%$ ) were recorded by Djitie et al., [13] as regards to the effect of crude protein level on growth and carcass in quail (Coturnix sp.) in the finishing phase in the Cameroon Highlands. Overall, T2 treatment induced the relatively higher gizzard proportions compared to the control group. This observation is contrary to that noted by Attia et al., [19] at 7 weeks of age in Coturnix japonica. Lower gizzard 
weights (2.23 to $3.59 \mathrm{~g}$ ) than ours were found by Makinde et al., [28]. This result would be due to hyperactivity of the gizzard in T2 treatment, which is the grinding muscle that crushes food by grinding effect allowed by its muscle power [29]. A difference in gizzard proportion was observed in favour of the females of the control batch compared to the males. It may be related to a higher consumption of the food by females in preparation for laying [30]. Relative abdominal fat weights were found to be higher in T2 treatment than in the males of the control batch [29]. A difference in gizzard proportion was observed in favour of the females of the control batch compared to the males. It may be related to a higher consumption of the food by females in preparation for laying [30]. Relative abdominal fat weights to body weight were similar to those of the control group and the relative weight of abdominal fat to body weight was relative and higher in the T2 group. Lower abdominal fat to live weight ratios $(0.13 \%)$ were reported by Attia et al., [19]. According to Lotfi et al., [31], abdominal fat is the largest adipose tissue in chickens. Studies have reported a visible increase in the size of subcutaneous fat in European quail during migration, confirming that subcutaneous fat is the main source of energy in migratory birds [31]. In fact, subcutaneous fat accounts for an average of $71.0 \%$ of total body fat in flying birds. Females develop more rapidly and produce larger muscles and more abdominal fat than males of the same age [31].

The present work showed that testicular weight remained comparable overall regardless of the substitution rate, although the highest was obtained with the $50 \%$ substitution treatment. The weight of the left testicle was almost always higher than that of the right testicle. This is consistent with previous studies, which found that the left testicle was, with few exceptions, always higher in the majority of birds [2, 32]. Testicular growth in the quails in our trial would be due to the better proliferation of Sertoli cells in this treatment and would result in an early attainment of sexual maturity. Their increase in size results in the development of the seminiferous tubes, which translates into a progressive increase in testicular weight and volume [33].

Laying rate in females of $\mathrm{T} 1$ treatment batches was $30.5 \%$ compared to $22 \%$ of the control batch and could be due to a better functioning of the reproductive system, feeds substituted at 25 and $75 \%$ would be better indicated for reproduction at the beginning of laying. The low production rate observed in this trial with the $\mathrm{T} 2$ and T4 treatments could be due to a delay in the beginning of laying compared to $\mathrm{T} 1$ and $\mathrm{T} 3$ treatments or to the weight of females in these treatments as it is well established that increased body weight in poultry has a negative effect on fertility [2]. Egg laying rate also varies between strains. It reaches $90 \%$ in Japanese quail and $80 \%$ in Italian broiler breeders [34]. According to Hassan [35], the average laying rate of Japanese quail is around $85 \%$. The low laying rates noted in our work are simply justified by the fact that birds are at the beginning of their laying careers.

In our trial, first eggs and first songs were observed with the females of treatment T2 at 6 weeks, in contrast to the observations made by Hassan [35] at 50 days with his control batch. Sexual maturity in other authors was observed between 60 and 62 days Odunsi et al., [18]. The shape index was not significantly influenced by different diets, all indices were close to that of the control group (0.82). The shape index, between 0.70 and $0.77 \%$, can be estimated as an optimal value in poultry Bensalah [14], but it should be noted that youngest layers give the highest shape indices and the most rounded eggs, which explains the values obtained in our experiment which was conducted during the first month of egg laying.

\section{CONCLUSION}

At the end of our study, the following conclusions were drawn:

- $50 \%$ maize bran substitution induced an increase of body weight and reduce feed conversion ratio.

- Overall, diets substituted at $50 \%$ and $75 \%$ by maize bran improved carcass yield and gizzard proportions compared to the control. Other carcass characteristics remain almost similar between groups.

- $50 \%$ maize bran substitution induced an increase in testicular weight and gonadosomatic index, and $25 \%$ increase laying rate and egg weight.

Well processed, maize bran can then be used as wheat bran substitute and $50 \%$ seems to be more indicated for growth and for sexual maturity in male while $25 \%$ seems to be more.

\section{REFERENCES}

1. Kayang BB, Vignal A, Inoue-Murayama $M$, Mmiva L, monvoisin J, Sito and Minvielle F. A first generation microsatellite linkage map of the Japanese quail. Animal Genetics. 2004; 35: 195 200.

2. Sauveur B. Reproduction des volailles et production d'œufs. INRA Paris France. 1988; 450.

3. Biagini F. Petits et mini-élevages dans le monde : principales espèces d'intérêt. Synthèse bibliographique. Biologie géosciences agro ressources et environnement productions animales en régions chaudes synthèse. École Nationale Supérieure Agronomique de Montpellier Place Viala, 34060 Montpellier Cedex Master. 2006; 31.

4. Tunsaringkarn T, Tungjaroenchai W, Siriwong W. Nutrient Benefits of Quail (Coturnix Coturnix Japonica) Eggs. International Journal of Scientific and Research Publications. 2013; 3(5):1-8.

5. Tendonkeng F, Boukila B, Beguide A, Pamo TE Essai de subtitution du tourteau de soja par la farine de feuilles de Moringa oleifera dans la 
ration finition des poulets de chair. Revue Africaine de Santé et de Productions Animales. 2009; 7(5).

6. Lunel SM, Krauskopf B. The mathematics of delay equations with an application to the LangKobayashi equations. InAIP Conference Proceedings 2000 Dec 11 (Vol. 548, No. 1, pp. 6686). American Institute of Physics.

7. Mbogning E, Tchoumboue J, Damasse F, Sobze MS, Canini A. Caractéristiques physico-chimiques des miels de la zone Soudano-guinéenne de L'Ouest et de l'Adamaoua.Tropicultura, 2011;(3):168-175.

8. Genchev A, Mihaylova G, Ribarski S, Pavlov A, Kabakchiev M 2008 Meat quality and composition in Japonese quails. Trakia Journal of Science. 6: 72-82.

9. Kiendrébéogo T. Diagnostic des élevages porcins de la zone de Bobo-Dioulasso: systèmes d'élevage et conditions technico-économiques de production. Mémoire de DEA en gestion intégrée des ressources naturelles option Productions Animales, Université Polytechnique de BoboDioulasso, Burkina Faso, 2005; 48.

10. Bobga A. Effet de la substitution de la farine de poisson par la farine de grillon sur les performances de production de la caille (Coturnix sp.) dans la zone soudano-guinéenne du Cameroun. Mémoire de Master, Université de Ngaoundéré, 2019; 64.

11. Djitie KF, Moussa D, Mamadou K, Friki LN, Aoudou B, Golomta P, Teguia A. Effect of feed supplementation by Moringa oleifera leaves meal on quail (Coturnix sp.) production performances in the sudano-guinean zone of cameroon. Scientific Works. Series C. Veterinary Medicine. 2019; Vol. LXV, Issue 2, 61-68. http://veterinarymedicinejournal.usamv.ro/pdf/201 9/issue_2/Art9.pdf

12. Broin M. Composition nutritionnelle des feuilles de Moringa oleifera. 2005; CTA. 5.

13. Djitie Kouatcho F, Kana JR, Ngoula F, Nana NFC, Teguia A. Effect of dietary crude protein level on growth parameters and carcass characteristics of quail (Coturnix sp) at finisher stage in Western Highlands of Cameroon. Livestock Research for Rural Development.2015; 27(8):1-10.

14. Bensalah A. Effets de quelques formules alimentaires sur les performances zootechniques et le profil biochimique de la caille japonaise. Mémoire de Magistère en sciences vétérinaire. Département de Productions Animales, Université des Frères Mentouri Constantine. 2016; 131.

15. Tesseraud S. Métabolisme protéique chez le poulet en croissance. Effet des protéines alimentaires. INRA Productions Animales. 1995;8:197-212.

16. Kita K, Muramatsu T, Okumura J. Influence of excess protein intake on whole-body protein synthesis in chicks. Nutrition reports international, 1989; 39: 1091-1097.
17. Leeson S and Summers JD. Commercial Poultry Nutrition 3ed Broiler chicken's broilers breeders laying hens game birds pet birds turkeys ratites ducks Geese. University of Guelph. Ontario, Canada. 2005; 11-85.

18. Odunsi AA, Rotimi AA, Amao EA. Effect of different vegetable protein sources on growth and laying performance of Japanese quails (Coturnix Coturnix Japonica) in a derived savannah zone of Nigeria. World Applied Sciences Journal. 2007; 3(5): 567-571.

19. Attia YA, Abd El-Hamid AE, Ellakany HF, Bovera F, Al-Harthi MA and Ghazaly SA. Growing and laying performance of Japanese quail fed diet supplemented with different concentrations of acetic acid. Italian Journal of Animal Science. 2013;12(e37): 222-229.

20. Ghally AK, Abd EL-Latif SA. Effect of dietary yeast on some productive and physiological aspects of growing Japanese quails. African Crop Science Conference Proceedings, 2007; 8: 21472151.

21. Kanyinji F, Moonga M. Effects of replacing maize meal with rumen filtrate-fermented cassava meal on growth and egg production performance in Japanese quails (Coturnix japonica). Journal of Advanced Veterinary and Animal Research, 2014; 1(3):100-106.

22. Berrama Z, Mefti H, Kaidi R, Souames S. Zootechnic characterization and genetics parameters of growth traits of japanese quail Coturnix japonica rearing in Algeria. 2011; 23.

23. Corrêa1 GSS, Silva MA, Corrêa AB, Fontes DO, Santos GG and Lima Neto HR. Crude protein level for meat type quail during the growing period. Arq Bras Med Vet Zootec, 2008; 60(1):209-217.

24. Bonos EM, Christaki EV and Florou-Paneri PC. Performance and carcass characteristics of Japanese quail as affected by sex or mannan oligosaccharides and calcium propionate. South African Journal of Animal Science. 2010; 40(3):173-181.

25. Alkan S, Karabağ K, Galiç A, Karsli T, Balcioğlu MS. Determination of Body Weight and Some Carcass Traits in Japanese Quails of Different Lines KafkasUniv Vet Fak Derg. 2010; 16(2): 277-280.

26. Vali N. Growth, feed consumption and carcass composition of Coturnix japonica, Coturnix ypsilophorus and their reciprocal crosses. Asian Journal of Poultry Science, 2006; 3(4):132-137.

27. Dolscheid S, Shayan S, Majid A, Casasanto D. The thickness of musical pitch: Psychophysical evidence for linguistic relativity. Psychological science. 2013 May; 24(5):613-21.

28. Makinde SC, Ariyo OJ, Akinbowale RI. Assessment of groundnut performance in different environments using Additive Main effects and Multiplicative Interaction (AMMI) model. 
Canadian Journal of Plant Breeding. 2013; 1(2):60-6.

29. Guérin J L, Balloy D, Villate D. Maladies des volailles, 3ème Edition France agricole, 2011;576.

30. Ojedapo LO, Amao SR. Sexual dimorphism on carcass characteristics of Japanase quail (Coturnix coturnix japonica) reared in derived savanna zone of Nigeria. International Journal of Science, Environment and Technology. 2014; 3(1):250257.

31. Narimani-Rad M, Nobakht A, Lotfi A. Influence of dietary supplemented semi-refined sunflower oil with vitamin $\mathrm{E}$ on some of serum biochemical and immunological measures in laying hens. Advances in Environmental Biology. 2011 Jun $1: 1955-60$.
32. Vatsalya V., Kashmiri L. A., Allometric Growth of Testes in Relation to Age, Body Weight and Selected Blood Parameters in Male Japanese Quail (Coturnix japonica). International Journal of poultry Science. 2012; 11(4): 251-258.

33. Denk AG, Kempenaers B. Testosterone and testes size in mallards (anas platyrhynchos). Journal of ornithology. 2005; 147: 436-440.

34. Romao JM, Moraes TGV, Silva EE, Teixeira RSC, Cardoso WM. Incubation of Japanese quail eggs stored at tropical temperatures. Livestock Research for Rural Development. 2010; 22(1).

35. Hassan HA. Variations in egg performance and plasma constituents at different ages of female's Japanese quail. Egyptian Poultry Science, 2010; 30(2):565-581. 